\title{
Temporal and depth responses of two temperate corals, Cladocora caespitosa and Oculina patagonica, from the North Mediterranean Sea
}

\author{
Riccardo Rodolfo-Metalpa ${ }^{1,2, *}$, Stephanie Reynaud ${ }^{1}$, Denis Allemand ${ }^{1}$, \\ Christine Ferrier-Pagès ${ }^{1}$ \\ ${ }^{1}$ Centre Scientifique de Monaco, Avenue Saint-Martin, 98000 Monaco \\ ${ }^{2}$ Present address: Marine Biology and Ecology Research Centre, Davy Building, University of Plymouth, \\ Plymouth PL4 8AA, UK
}

\begin{abstract}
The effects of light and temperature on the growth and effective quantum yield $\left(\Delta F / F_{\mathrm{m}}{ }^{\prime}\right)$ of the scleractinian corals Cladocora caespitosa and Oculina patagonica distributed between 3 and $18 \mathrm{~m}$ depth was investigated for $18 \mathrm{mo}$ in 2005-2006. Their growth rates, zooxanthellae and chlorophyll concentrations generally increased from winter to spring, and decreased from early summer to autumn. O. patagonica behaved like a tropical coral with respect to growth enhancement with increasing light intensities and temperature, whereas C. caespitosa acted more as a temperate coral; its growth was enhanced by increasing temperature, not irradiance. By contrast, $\Delta F / F_{\mathrm{m}}{ }^{\prime}$ did not show any relationship with environmental parameters, but was significantly lower in shallow colonies, reflecting some down-regulation of photosystem II. Mean photosynthetically active radiation received by shallow water corals during summer (1000 to $1400 \mu \mathrm{mol} \mathrm{m}^{-2} \mathrm{~s}^{-1}$ ) was as high as in some tropical regions. However, the diel cycle of $\Delta F / F_{\mathrm{m}}$ ' only showed a slight decrease at midday with a quick recovery soon afterwards, suggesting that the symbionts were either protected by coral pigments or adapted to light levels much higher than those usually experienced. Since C. caespitosa is mostly found in turbid environments and rarely in well-lit waters, its distribution in shallow water may be limited by factors other than light, such as competition with macroalgae. Results also showed that the 2 species inhabiting the NW Mediterranean Sea are under stress when temperatures become extremely cold or warm, during winters and summers, respectively.
\end{abstract}

KEY WORDS: Temperate corals - Mediterranean Sea · Seasonal variation · Coral mortality Zooxanthellae $\cdot$ Coral growth $\cdot$ PAM fluorometry

\section{INTRODUCTION}

Temperate seas, such as the northern part of the Mediterranean, undergo pronounced seasonal variation in environmental parameters such as temperature and light intensity (Muller-Parker \& Davy 2001). Daily integrated irradiance fluxes in such regions are 4 to 7 times higher in summer than in winter, and temperature can be 2 to 3 times higher in summer (MullerParker \& Davy 2001). Food availability for sessile organisms also varies, and is often higher in winter than in summer, when a thermocline isolates the upper part of the euphotic zone (Coma et al. 2000). Most of the existing research on the temporal or seasonal effects on Mediterranean sessile benthos has been carried out on non-symbiotic species, such as gorgonians and sponges (e.g. Coma et al. 2000, 2002). These organisms exhibit a decrease in their metabolic rates (respiration and growth), both in winter (dormancy) due to low temperatures, and in summer (aestivation) due to food shortage (Coma et al. 2002).

Although 5 scleractinian coral species have zooxanthellae symbionts in the Mediterranean (Zibrowius 1980), few studies have addressed their response to 
temporal or depth environmental changes. These studies can be summarized by the following 3 points: (1) no difference was found in zooxanthellae density and chlorophyll (chl) content of Cladocora caespitosa between 3 and 12 m depth (Schiller 1993); (2) C. caespitosa showed slight temporal changes in the rates of photosynthesis and was shown to deposit 2 skeletal bands during winter and summer periods (Schiller 1993, Peirano et al. 1999, 2005); and (3) summer bleaching of Oculina patagonica occurred on the Israeli coasts (e.g. Shenkar et al. 2006). Our knowledge of the response of symbiotic corals to in situ changes in temperature and irradiance is restricted to studies of tropical species which acclimate to the small seasonal variations in their environment by changing their growth rates (Vago et al. 1997), zooxanthellae and pigment concentrations (Stimson 1997, Brown et al. 1999b), as well as their photosynthetic efficiency (Warner et al. 2002, Winters et al. 2006). Shallow-water tropical corals also show marked diel photoinhibition (Brown et al. 1999a, Jones \& Hoegh-Guldberg 2001, Lesser \& Gorbunov 2001, Winters et al. 2003).

In the Mediterranean Sea, the 2 most abundant symbiotic corals are Cladocora caespitosa and Oculina patagonica. The former is an endemic coral present throughout the entire Mediterranean (Zibrowius 1980), while the latter is considered an immigrant species abundant in the south of the basin (Israel, Lebanon, Egypt) and in Spain, and is represented by few colonies in the Ligurian Sea (see Fine et al. 2001 for a review). The corals range in depth from 0.5 to $15 \mathrm{~m}$ for O. patagonica, and from 5 to $40 \mathrm{~m}$ for C. Caespitosa, although it is rarely found below $30 \mathrm{~m}$. Both species are well adapted to turbid coastal environments with high sedimentation rates (Peirano et al. 2005). This broad distribution suggests that these corals and their associated symbionts are able to acclimate to the large range of light levels (10 to $250 \mu \mathrm{mol} \mathrm{m} \mathrm{m}^{-2} \mathrm{~s}^{-1}$ in the Ligurian Sea, Peirano et al. 1999) and temperatures (from 16 to $31^{\circ} \mathrm{C}$ along the Israeli coasts; and from 13 to $26^{\circ} \mathrm{C}$ in the Ligurian Sea).

The present study monitored the response of 2 symbiotic corals, Cladocora caespitosa and Oculina patagonica, to changes in their environmental parameters over an 18 mo period (June 2005 to December 2006). Changes in growth rate, zooxanthellae density, chl concentration and the effective quantum yield $\left(\Delta F / F_{\mathrm{m}}{ }^{\prime}\right)$ of C. caespitosa and O. patagonica colonies were monitored in parallel to temperature and irradiance. In addition, the diel cycle of $\Delta F / F_{\mathrm{m}}$ ' was measured during July 2005 and 2006, when temperature and irradiance were at their highest annual levels, to compare the response of these temperate corals with those of tropical corals, which severely decrease their yield at midday under high irradiance.

\section{MATERIALS AND METHODS}

Coral sampling and transplantation. In March 2005, 18 small (10 to $20 \mathrm{~cm}$ diameter) colonies of Cladocora caespitosa were collected in the Gulf of La Spezia (Ligurian Sea, $44^{\circ} 03^{\prime} \mathrm{N}, 9^{\circ} 55^{\prime} \mathrm{E}$ ) at 7 to $9 \mathrm{~m}$ depth. We also sampled 135 colony fragments (nubbins) of $\mathrm{Ocu}-$ lina patagonica (5 to $7 \mathrm{~cm}^{2}$ ) at Albissola (Ligurian Sea, $\left.44^{\circ} 17^{\prime} \mathrm{N}, 8^{\circ} 30^{\prime} \mathrm{E}\right)$. Collected colonies and nubbins were transported in thermostated tanks to the laboratory where they were maintained in aquaria continuously supplied with running Mediterranean seawater pumped from $50 \mathrm{~m}$ depth. Turnover rate of seawater in the aquaria was $20 \% \mathrm{~h}^{-1}$ and temperature was maintained at $14^{\circ} \mathrm{C}$ (as measured at the site of collection). Three days later, 3 colonies of C. caespitosa were divided into 30 nubbins, each one containing 10 to 15 polyps, which were carefully cleaned of epiphytes, associated fauna, and sediment. All nubbins from the 2 coral species, as well as the remaining colonies of C. caespitosa, were glued using epoxy (HoldFast ${ }^{\circledR}$ ) on individually tagged plastic plates (see subsection 'Growth rates') that were individually screwed onto several PVC screens containing 5 to 10 nubbins each. These screens were immediately transplanted onto seawalls located near the Oceanographic Museum $\left(44^{\circ} 44^{\prime} \mathrm{N}, 7^{\circ} 25^{\prime} \mathrm{E}\right)$, near resident $C$. caespitosa colonies. Screens were fixed to light exposed breakwaters lacking macroalgae to prevent direct competition between the corals and macroalgae and were positioned at 3 relevant ecological depths: 3, 6, and $11 \mathrm{~m}$ for $O$. patagonica; and 6, 11 and $18 \mathrm{~m}$ for C. caespitosa. For each depth, a total of 15 and 10 nubbins of $O$. patagonica and C. caespitosa, respectively, were transplanted and measured for growth rate during the experiment. Another 35 nubbins of $O$. patagonica and 5 whole colonies of $C$. caespitosa ( $\mathrm{n}=5$ for each depth) were added for zooxanthellae and chl content measurements.

One week after the transplantation, $\Delta F / F_{\mathrm{m}}$ ' was measured (see subsection 'Chlorophyll fluorescence measurements') on the transplanted Cladocora caespitosa and compared to that measured on resident colonies positioned at the same depth. Results showed no difference in $\Delta F / F_{\mathrm{m}}$ ' between the 2 populations, suggesting that the corals did not suffer from transplantation. Corals were however allowed to acclimate for $3 \mathrm{mo}$ before the physiological measurements. Every 2 mo during the subsequent $18 \mathrm{mo}$, growth rates and photosynthetic efficiency of both coral species were measured and some samples (see 'Material and methods') were collected for symbiont and protein measurements using forceps.

Growth rates. Thirty nubbins of Cladocora caespitosa (10 for each depth) and 45 nubbins of Oculina patagonica (15 for each depth) were prepared before 
the transplantation for growth rate measurement. Corals were weighed using the buoyant weight technique (Spencer Davies 1989) before and after being glued onto individual plastic plates, and the difference was recorded. After a 3 mo acclimation period, and every 2 mo thereafter, nubbins were taken back to the laboratory where they were maintained for $2 \mathrm{~d}$ in aquaria under similar temperature and irradiance levels to those experienced in situ. They were unscrewed from the plates, carefully cleaned of epiphytes and encrusting algae, and weighed. All corals were subsequently re-transplanted to their corresponding depth.

The net buoyant weight of the corals (total coral weight minus the weight of each plate) was converted into dry weight following the method of Spencer Davies (1989), using coral skeleton densities of 2.20 and $1.86 \mathrm{~g} \mathrm{~cm}^{-3}$ for Oculina patagonica and Cladocora caespitosa, respectively (R. Rodolfo-Metalpa unpubl. data). Daily growth rates were calculated as the change in dry weight between 2 periods of measurement and normalized to surface area of living tissue for C. caespitosa and to the initial weight for O. patagonica. The difference in the normalization procedure (see Rodolfo-Metalpa et al. 2006) is due to the fact that C. caespitosa is phaceloid (i.e. polyps are only present on the apical part of separate corallites) while $O$. patagonica is an encrusting, plocoid coral able to grow both laterally by coenosarc accretion and vertically by depositing new dense skeleton on the original one. For O. patagonica, the newly formed planar surface skeleton was also estimated from April to November 2006 on 7 similar-sized nubbins sampled at each depth using digital photographs and image analysis software (open-access ImageJ).

Chlorophyll fluorescence measurements. Variations in the effective quantum yield of photosystem II (PSII), a way to assess the photosynthetic performances of PSII, were measured during the 18 mo study using an underwater pulse-amplitude modulated (PAM) fluorometer (Diving-PAM, Walz) on random nubbins sampled at each depth and for each species, on clear days at solar midday. The $8 \mathrm{~mm}$ fiber was placed at a fixed distance of $5 \mathrm{~mm}$ from the coral tissue using a black jacket (Rodolfo-Metalpa et al. 2006). After 5 to $10 \mathrm{~s}$, the effective quantum yield $\left(\Delta F / F_{\mathrm{m}}{ }^{\prime}\right)$ was measured by exposing 7 to 8 nubbins separately to a 0.8 s period of saturating light $\left(\sim 8000 \mu \mathrm{mol} \mathrm{m} \mathrm{m}^{-2} \mathrm{~s}^{-1}\right)$. In addition, the diel change in the $\Delta F / F_{\mathrm{m}}{ }^{\prime}$ was also measured during summer (14 July 2005 and 29 July 2006), when temperature and light were at their maximum and could potentially produce a variation in the photosynthetic parameters. Measurements were repeated every $2 \mathrm{~h}(\mathrm{n}=9)$ on a sunny day from dawn $(06: 30 \mathrm{~h})$ to sunset $(20: 00 \mathrm{~h})$. $\Delta F / F_{\mathrm{m}}{ }^{\prime}$ was measured at 3 and $11 \mathrm{~m}$ depth for Oculina patagonica and Cladocora caespitosa, respectively.
Depths were chosen according to the natural distribution of the 2 species, which are most abundant at 3 and $11 \mathrm{~m}$ depths, respectively. Concomitantly, PAR at the 2 depths was continuously recorded using LiCor instruments as described in 'Environmental parameters'.

Chlorophyll and zooxanthellae determinations. Three nubbins of Oculina patagonica and 5 single polyps (from 5 different colonies) of Cladocora caespitosa were collected at each depth and each sampling time for zooxanthellae and chl measurements. Samples were frozen at $-80^{\circ} \mathrm{C}$ and tissue was removed using a Water Pick and processed as described in Rodolfo-Metalpa et al. (2006). $\mathrm{Chl} \mathrm{a}$ and $C_{2}$ were extracted in pure acetone at $4^{\circ} \mathrm{C}$ for $24 \mathrm{~h}$ and determined according to the equations of Jeffrey \& Humphrey (1975) on a spectrophotometer. Zooxanthellae were counted (number of fields $=10$ ) using an inverse microscope and an improved version of the Histolab $^{\text {TM }}$ 5.2.3 image analysis software. Data were normalized to skeletal surface area, which was calculated by measuring polyp dimensions for C. caespitosa (Rodolfo-Metalpa et al. 2006) or using the aluminum foil technique (Marsh 1970) for O. patagonica.

Environmental parameters. During each sampling period, scalar PAR irradiance was measured at 0, 3, 6, 11 and $18 \mathrm{~m}$ depth at solar midday always under a clear sky and flat sea. A spherical quantum sensor (LiCor LI-193) was placed near the nubbins and light values (20 instantaneous measurements) were recorded using a LiCor LI-1000. These measurements were considered the maximum light level experienced by the corals at the time of collection. From these in situ measurements, depth attenuation coefficients were calculated for each incubation period. These coefficients were applied to global terrestrial radiation data (Nice, $43^{\circ} 39^{\prime} \mathrm{N}, 7^{\circ} 12^{\prime} \mathrm{E}$, Meteo France data, $\mathrm{J} \mathrm{cm}^{-2}$ ) to calculate the total radiation received by the corals during each incubation period. Seawater temperatures were measured every hour using Onset HOBO pro data loggers placed at 3,11 and $18 \mathrm{~m}$ depth.

To relate physiological measurements (taken every $2 \mathrm{mo}$ ) to environmental parameters, mean seawater temperatures and mean total radiation received by the corals were calculated for each depth during each sampling interval and used in the regression analyses.

Statistical analysis. $\Delta F / F_{\mathrm{m}}{ }^{\prime}$, zooxanthellae and chl concentrations for each species were compared via a 2-way ANOVA with 2 fixed orthogonal factors, depth (3 levels) and time (9 or 10 levels, according to the parameter considered), using STATISTICA ${ }^{\circledR}$ (Statsoft). In contrast, growth rates were measured on the same nubbins during the entire experiment. Therefore, 2-way repeated measures ANOVA was used. When ANOVAs revealed significant differences $(p<0.05)$, Tukey's HSD or Tukey's HSD for unequal numbers (Spjotvoll/Stoline test) were used to compare mean 
values between depths. Due to the mortality of Cladocora caespitosa nubbins during August 2005 (see 'Results'), and the necessity to acclimate new nubbins for 2 to $3 \mathrm{mo}$, it was impossible to measure the growth of this species over the entire 18 mo period.

Because physiological measurements were made every $2 \mathrm{mo}$, the individual and combined relationships between temperature, total radiation $\left(\mathrm{J} \mathrm{m}^{-2}\right)$ and coral growth or symbiont parameters were assessed by multiple regression analyses using the mean temperature and radiation calculated between 2 physiological measurements.

Homogeneity of variance was tested on all datasets using Cochran's test. Significant differences were assessed at $p<0.05$ or at $p<0.01$ when homogeneity could not be achieved through log-transformation (Underwood 1997). Results are presented as mean \pm SE throughout.

\section{RESULTS}

\section{Environmental parameters}

Monthly global radiation (Fig. 1a) and PAR measured at the 3 depths (Fig. 1b) greatly varied according to the time of collection. PAR values at $3 \mathrm{~m}$ were equal to 1400 and $570 \mu \mathrm{mol} \mathrm{m}^{-2} \mathrm{~s}^{-1}$ in July and December 2005, respectively. The attenuation coefficient was about 60 to $80 \%$ between 0 and $18 \mathrm{~m}$ depth. Fig. 2 shows the mean PAR level measured from dawn to sunset during July 2005 at 3 and $11 \mathrm{~m}$ depth. In deep waters, PAR is quite consistent during the day around 400 to $500 \mu \mathrm{mol} \mathrm{m}^{-2}$ $\mathrm{s}^{-1}$. In contrast, shallow water corals are exposed to higher PAR values (mean around $1400 \mu \mathrm{mol} \mathrm{m}{ }^{-2} \mathrm{~s}^{-1}$ ) that reached peaks of $3000 \mu \mathrm{mol} \mathrm{m}^{-2} \mathrm{~s}^{-1}$ or more; however, it is variable in surface waters.

Mean temperature values varied from approximately $13^{\circ} \mathrm{C}$ during January-March to $24^{\circ} \mathrm{C}$ during July-September with a slight decrease with depth (Fig. 1C). The lowest $\left(11.8^{\circ} \mathrm{C}\right.$, February 2006) and highest $\left(27.8^{\circ} \mathrm{C}\right.$, August 2006$)$ values were measured at $3 \mathrm{~m}$ depth. From June to October 2005, $45 \%$ of the temperature data (daily mean values calculated from hourly measurements) at $3 \mathrm{~m}$ depth were above $24^{\circ} \mathrm{C}$, representing a total of about $8 \mathrm{wk}$ of high temperatures. In contrast, except for the presence of hot spots, only $30 \%$ of the temperature data remained above $24^{\circ} \mathrm{C}$ during the summer of 2006, corresponding to a total of $5 \mathrm{wk}$.

\section{Coral mortality and tissue regeneration}

At the end of August 2005, during a long period of elevated temperatures equal to or above $24^{\circ} \mathrm{C}$ (see
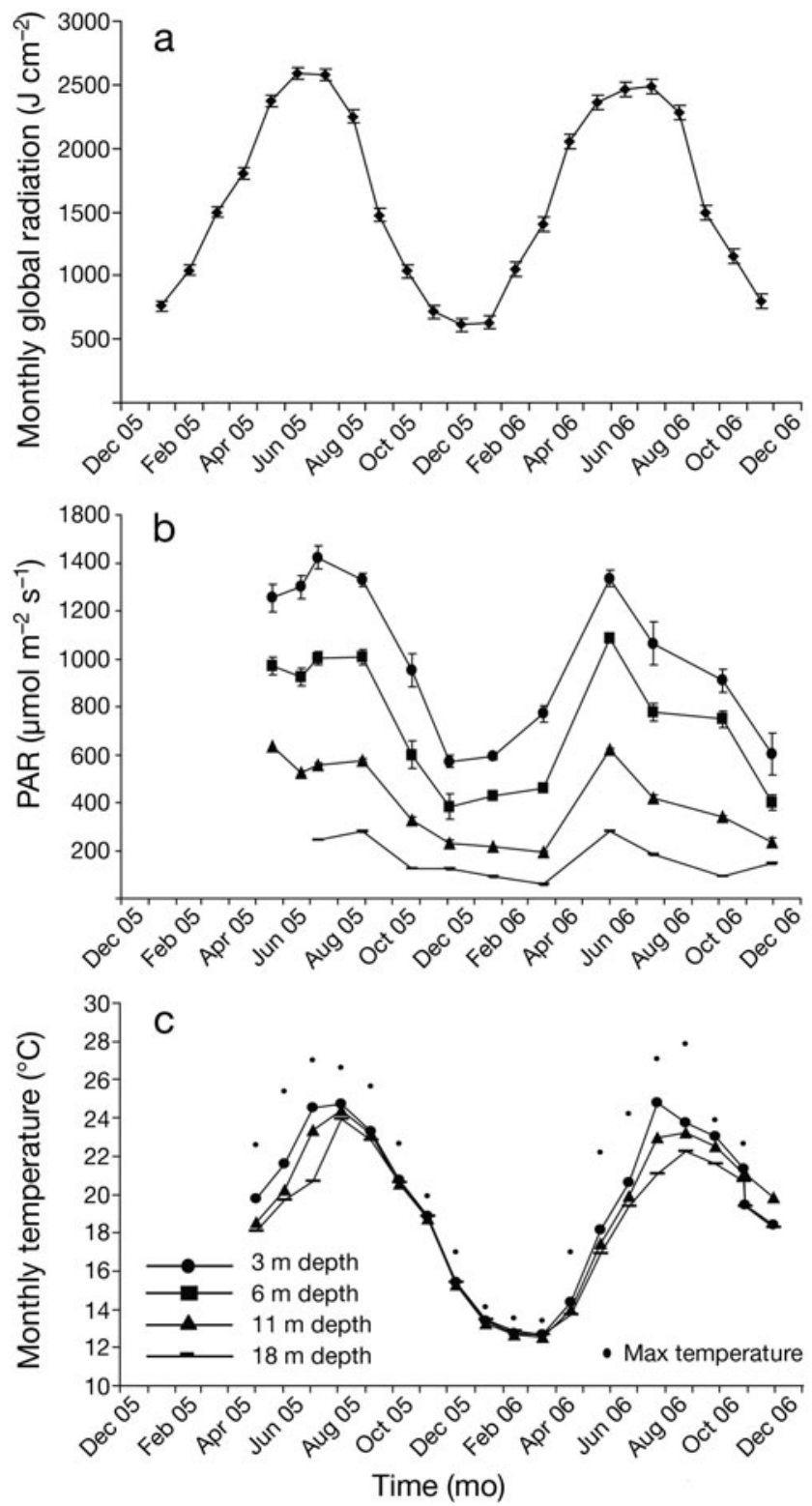

Fig. 1. (a) Monthly global radiation near Monaco (Nice, $\left.43^{\circ} 39^{\prime} \mathrm{N}, 7^{\circ} 12^{\prime} \mathrm{E}\right)$ measured by the national meteorological service (Meteo France); data are mean $( \pm$ SE) daily global measurements. (b) PAR measured at solar midday under clear sky and flat sea, from 3 to $18 \mathrm{~m}$ depth using a LiCor spherical quantum sensor; data are mean $\left( \pm \mathrm{SE}_{;} \mathrm{n}=10\right)$. (c) Monthly seawater temperature measured at 3,11 and $18 \mathrm{~m}$ depth using Onset $\mathrm{HOBO}{ }^{\circledR}$ pro data loggers; data are mean $( \pm \mathrm{SE})$ of hourly measurements

'Environmental parameters'), several Oculina patagonica nubbins suffered from tissue degradation. In some cases, mortality only affected the coenosarc, leaving the contracted polyps in the calyx, while in other samples it affected the entire polyp, leaving the denuded skeleton (Fig. 3). Approximately $30 \%$ of transplanted nubbins were affected by partial or total mortality 


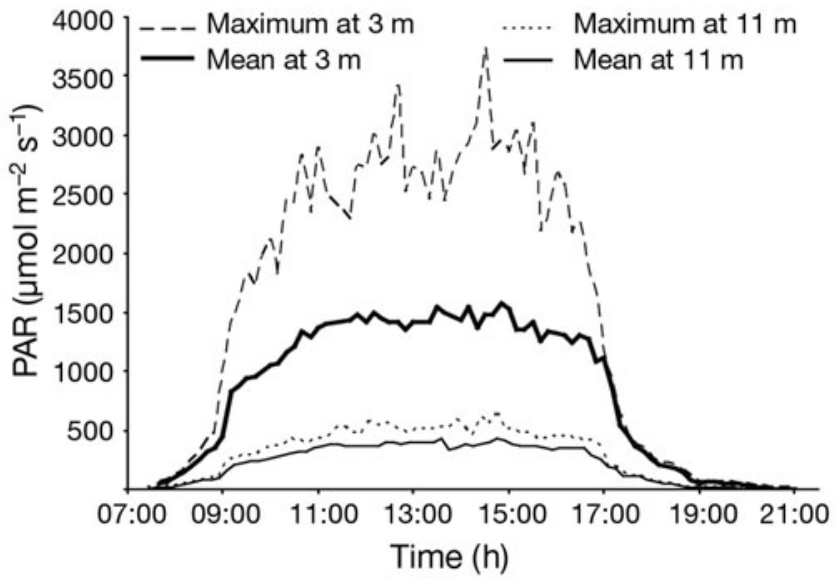

Fig. 2. Diel cycle of PAR levels measured in August 2005 from dawn to sunset near the transplanted corals at $3 \mathrm{~m}$ (Oculina patagonica) and $11 \mathrm{~m}$ depth (Cladocora caespitosa). Values were recorded every minute using a LiCor spherical quantum sensor regardless of depth; all these samples were excluded from growth rate measurements and used to estimate tissue regeneration by digital photographs. Results showed that $O$. patagonica was able to recover from 30 to $100 \%$ of the damaged surface area before the end of the experiment. Tissue regeneration was faster (3 to $4 \mathrm{~cm} \mathrm{mo}^{-1}$ ) when only the coenosarc was damaged and slower ( 1 to $2 \mathrm{~cm} \mathrm{mo}^{-1}$ ) or absent on nubbins presenting both coenosarc and polyp damage. Their skeletons were gradually settled by fouling organisms. A similar mortality event was observed in February 2006 during a prolonged period of low temperatures. Five to $20 \%$ of O. patagonica surface area was damaged; however, in this case, only $10 \%$ of samples showed general coenosarc degradation. In this subset of samples, tissue regeneration was complete by May 2006.

Concomitant to the Oculina patagonica mortality event, $83 \%$ (25 out of 30) of Cladocora caespitosa nub-
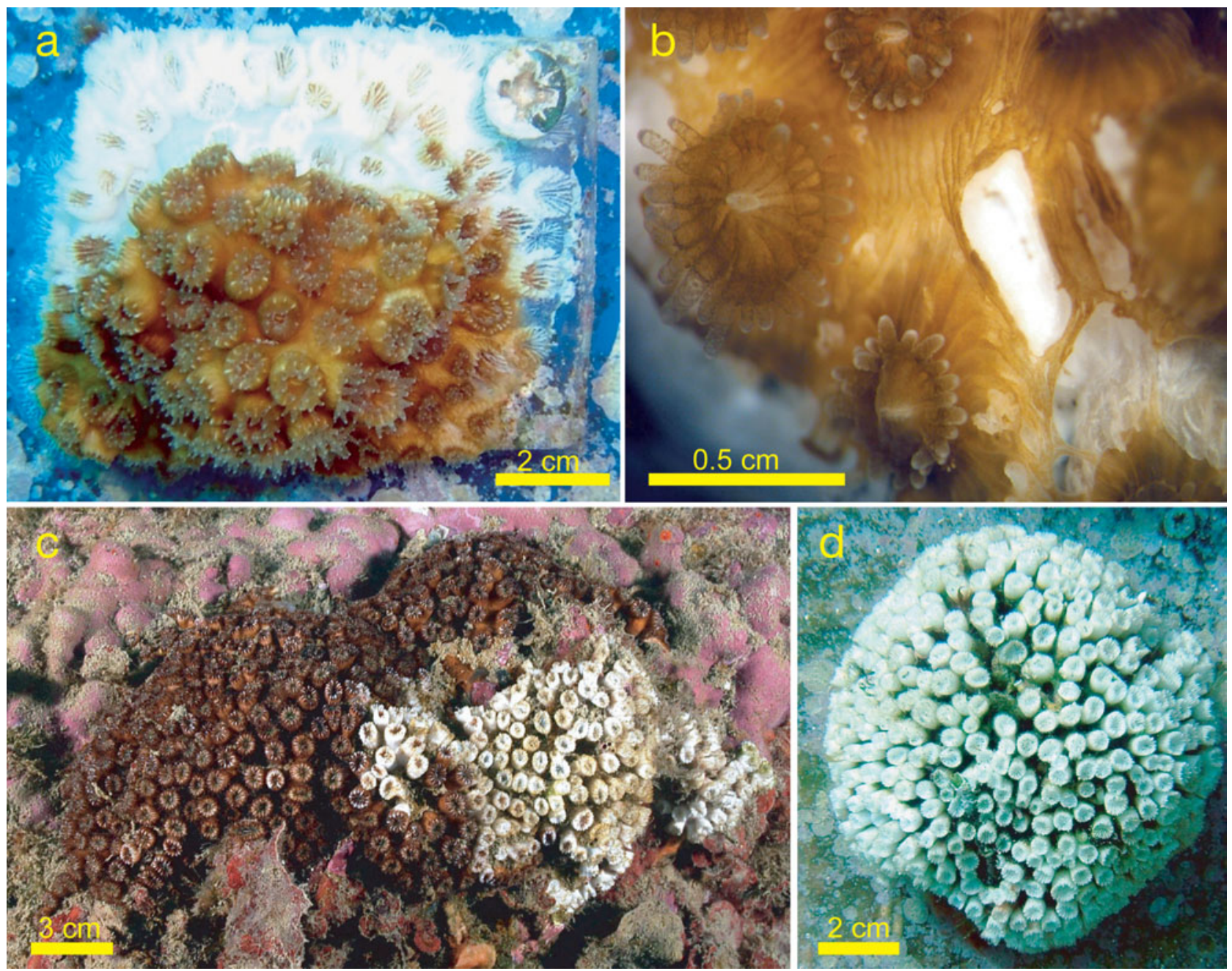

Fig. 3. $(\mathrm{a}, \mathrm{b})$ Colonies of Oculina patagonica and $(\mathrm{c}, \mathrm{d})$ nubbins of Cladocora caespitosa partially or totally damaged by the higher temperatures experienced during August 2005. (c) Provided by R. Graille (CNRS, Marseille) 
bins used to measure the growth rate and 5 out of 15 colonies died regardless of depth (Fig. 3). Polyps either completely disappeared from the calyx or showed evident signs of tissue degradation as previously reported for this species (Rodolfo-Metalpa et al. 2000, 2006). These nubbins and colonies were replaced by new samples at the end of the summer period, and were acclimated for 3 mo before any measurements were made. During the summer of 2006, no mortality event was observed either for C. caespitosa or O. patagonica.

\section{Zooxanthellae and chlorophyll concentrations}

Zooxanthellae density and chl content in Oculina patagonica varied significantly according to depth and time of collection (Table 1, Figs. 4a \& 5a). Zooxanthellae and pigment concentrations did not show any significant relationships with either temperature or light radiation, nor with the combination of both parameters (Multiple regression, $\mathrm{p}>0.05, \mathrm{n}=9$ ), although a general increase in both parameters was found from winter to spring, followed by a decrease during summer.

For Cladocora caespitosa, zooxanthellae and chl concentrations varied significantly between depth, time of collection and their interaction (Table 1, Figs. 4b \& 5b). Multiple regression analysis showed a significant correlation $(\mathrm{p}<0.05, \mathrm{n}=9)$ between zooxanthellae densities (at all depths) or the chl content (at 11 and $18 \mathrm{~m}$ depth) and the interaction of temperature and light radiation. Despite the great variability of the data, algal density showed (1) a decrease from early summer to autumn followed by a general increase from

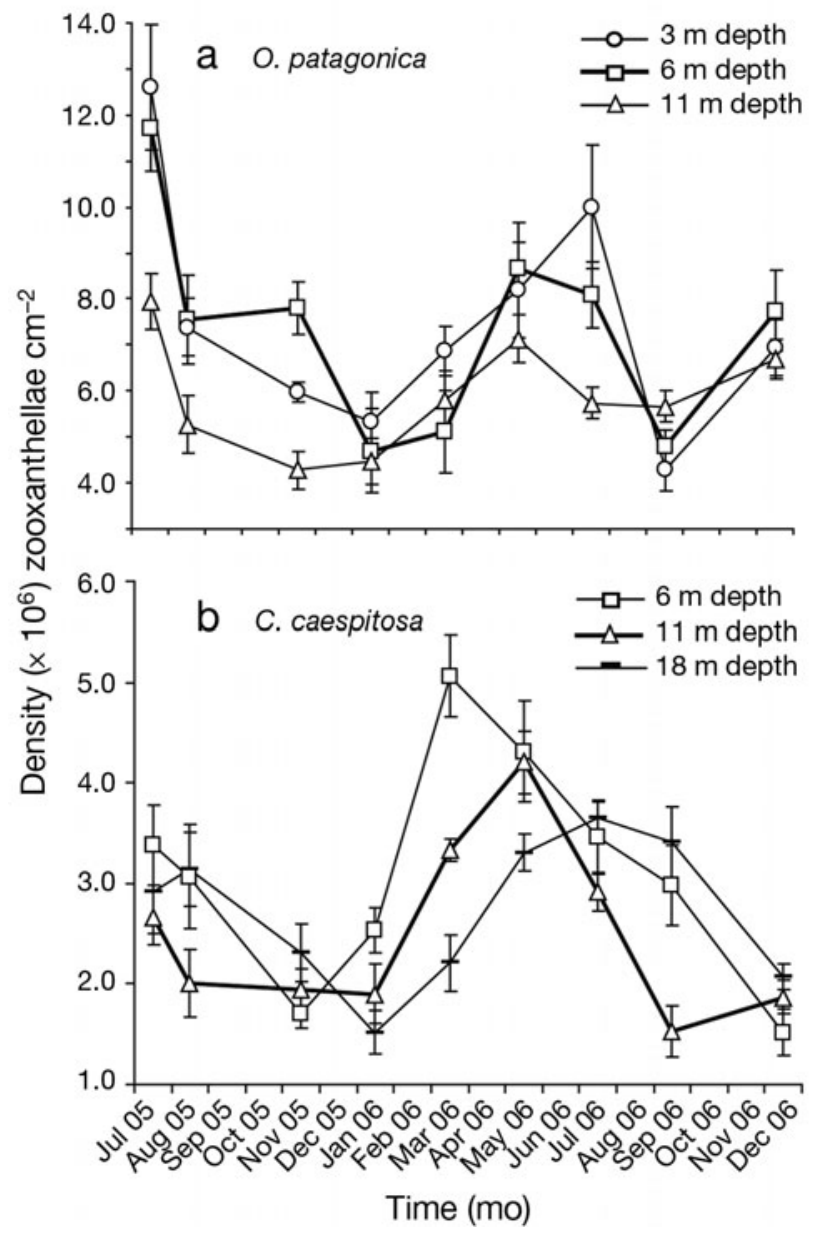

Fig. 4. Mean $( \pm \mathrm{SE})$ zooxanthellae density of (a) Oculina patagonica $(\mathrm{n}=3)$ and $(\mathrm{b})$ Cladocora caespitosa $(\mathrm{n}=5)$ measured at each depth during the entire experiment

Table 1. Summary of 2-way ANOVAs and post-hoc comparisons (Tukey's test), testing the effect of time of collection (July 2005 to December 2006: 9-10 levels) and depth (3 levels) on Oculina patagonica and Cladocora caespitosa. Tukey's tests were performed only between depths (3, 6, and 11 for $O$. patagonica; 6, 11, and 18 for C. caespitosa). Different letters (a, b, c) show significant differences $(\mathrm{p}<0.05)$

\begin{tabular}{|c|c|c|c|c|c|c|c|c|}
\hline & & Oculit & tagonica & & & Clado & caespitosa & \\
\hline & df & $F$ & $\mathrm{p}$ & Tukey's test & $\mathrm{df}$ & $F$ & $\mathrm{p}$ & Tukey's test \\
\hline Zooxanthell & ooxanthell & $\mathrm{cm}^{-2}$ ) & & & & & & \\
\hline Time $(\mathrm{T})$ & $(8,57)$ & 11.7 & $<0.001$ & & $(8,105)$ & 17.0 & $<0.001$ & \\
\hline Depth (D) & $(2,57)$ & 7.5 & $<0.01$ & $3^{\mathrm{a}}: 6^{\mathrm{a}}: 11^{\mathrm{b}}$ & $(2,105)$ & 9.2 & $<0.001$ & $6^{\mathrm{a}}: 11^{\mathrm{b}}: 18^{\mathrm{b}}$ \\
\hline $\mathrm{T} \times \mathrm{D}$ & $(16,57)$ & 1.6 & $>0.05$ & & $(16,105)$ & 4.8 & $<0.001$ & \\
\hline Chlorophyl & & & & & & & & \\
\hline Time & $(8,57)$ & 5.4 & $<0.001$ & & $(8,105)$ & 16.89 & $<0.001$ & \\
\hline Depth & $(2,57)$ & 10.2 & $<0.001$ & $3^{\mathrm{a}}: 6^{\mathrm{a}}: 11^{\mathrm{b}}$ & $(2,105)$ & 15.97 & $<0.001$ & $6^{\mathrm{a}}: 11^{\mathrm{b}}: 18^{\mathrm{c}}$ \\
\hline $\mathrm{T} \times \mathrm{D}$ & $(16,57)$ & 3.9 & $<0.001$ & & $(16,105)$ & 5.9 & $<0.001$ & \\
\hline$\Delta F / F_{\mathrm{m}}^{\prime}$ & & & & & & & & \\
\hline Time & $(9,210)$ & 19.2 & $<0.001$ & & $(9,182)$ & 9.4 & $<0.001$ & \\
\hline Depth & $(2,210)$ & 64.4 & $<0.001$ & $3^{\mathrm{a}}: 6^{\mathrm{a}}: 11^{\mathrm{b}}$ & $(2,182)$ & 68.1 & $<0.001$ & $6^{\mathrm{a}}: 11^{\mathrm{b}}: 18^{\mathrm{c}}$ \\
\hline $\mathrm{T} \times \mathrm{D}$ & $(18,210)$ & 3.7 & $<0.001$ & & $(18,182)$ & 5.7 & $<0.001$ & \\
\hline Growth $(\mathrm{mg}$ & O. patago & $a$ and & $\mathrm{cm}^{-2} \mathrm{~d}^{-1}$ fo & C. caespitosa & & & & \\
\hline Time & $(9,153)$ & 42.5 & $<0.001$ & & $(6,90)$ & 29.5 & $<0.001$ & \\
\hline Depth & $(2,17)$ & 14.6 & $<0.001$ & $3^{\mathrm{a}}: 6^{\mathrm{a}}: 11^{\mathrm{b}}$ & $(2,15)$ & 0.7 & $>0.05$ & \\
\hline $\mathrm{T} \times \mathrm{D}$ & $(18,153)$ & 4.3 & $<0.001$ & & $(12,90)$ & 0.9 & $>0.05$ & \\
\hline
\end{tabular}




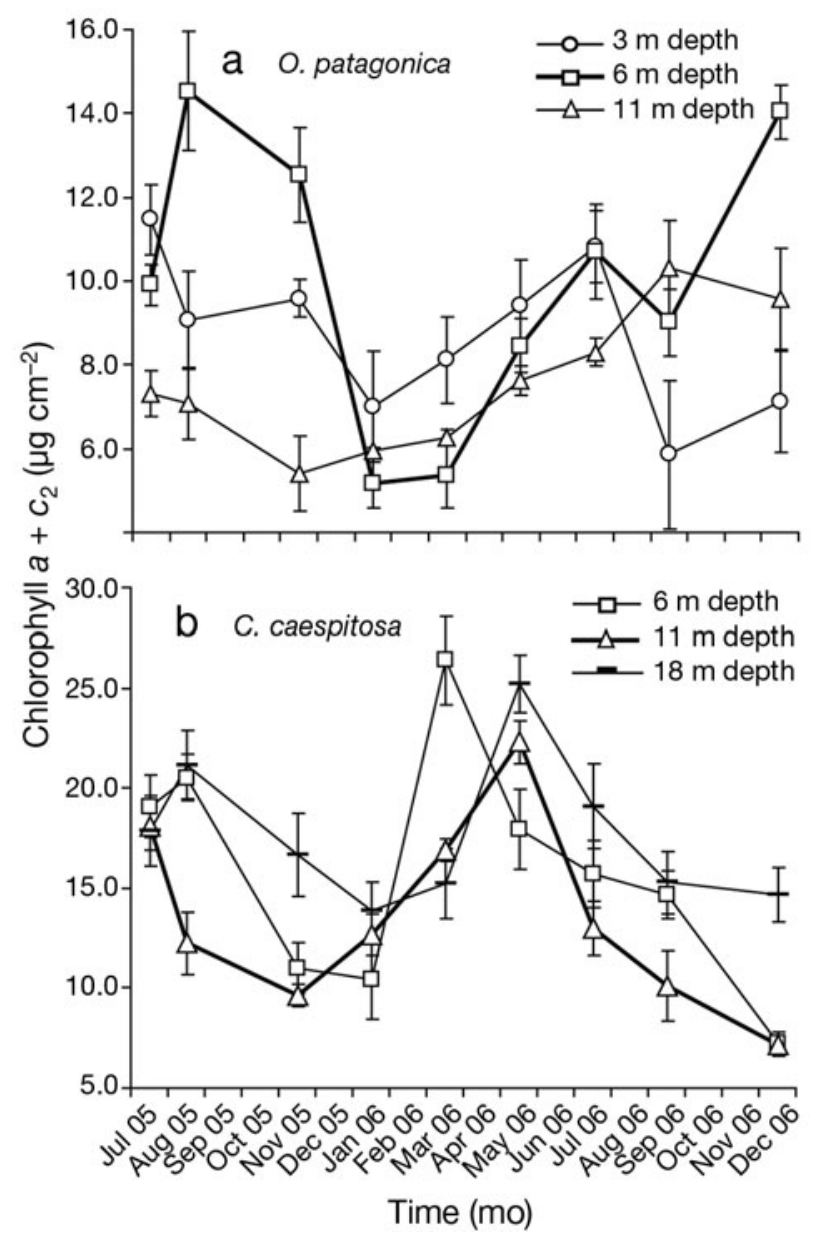

Fig. 5. Mean $( \pm \mathrm{SE})$ chlorophyll content of (a) Oculina patagonica $(\mathrm{n}=3)$ and $(\mathrm{b})$ Cladocora caespitosa $(\mathrm{n}=5)$ collected at each depth during the entire experiment

winter to spring, and (2) a decrease from shallow to deep colonies. Chl concentrations (1) increased from November-January 2005 to March-May 2006, and (2) did not show a clear pattern between depth.

\section{Chlorophyll fluorescence yield}

Effective quantum yield $\left(\Delta F / F_{\mathrm{m}}{ }^{\prime}\right)$ significantly varied for both species with depth and time of collection (Table 1). For Oculina patagonica (Fig. 6a), $\Delta F / F_{\mathrm{m}}{ }^{\prime}$ showed the greatest variation at 3 and $6 \mathrm{~m}$ depth, ranging from 0.39 (3 m, January 2006) to 0.61 (6 m, December 2006). Conversely, at $11 \mathrm{~m}$ depth, $\Delta F / F_{\mathrm{m}}{ }^{\prime}$ values were more stable (range $=0.55$ to 0.63 ) and always higher than at 3 and $6 \mathrm{~m}$ depth. For Cladocora caespitosa (Fig. 6b), $\Delta F / F_{\mathrm{m}}{ }^{\prime}$ was significantly higher at $18 \mathrm{~m}$ than at 11 or $6 \mathrm{~m}$ depth (Table 1). For both corals, $\Delta F / F_{\mathrm{m}}{ }^{\prime}$ variation did not show any relationship with either temperature or light radiation or their interaction (Multiple regression; $\mathrm{p}>0.05, \mathrm{n}=9$ ).

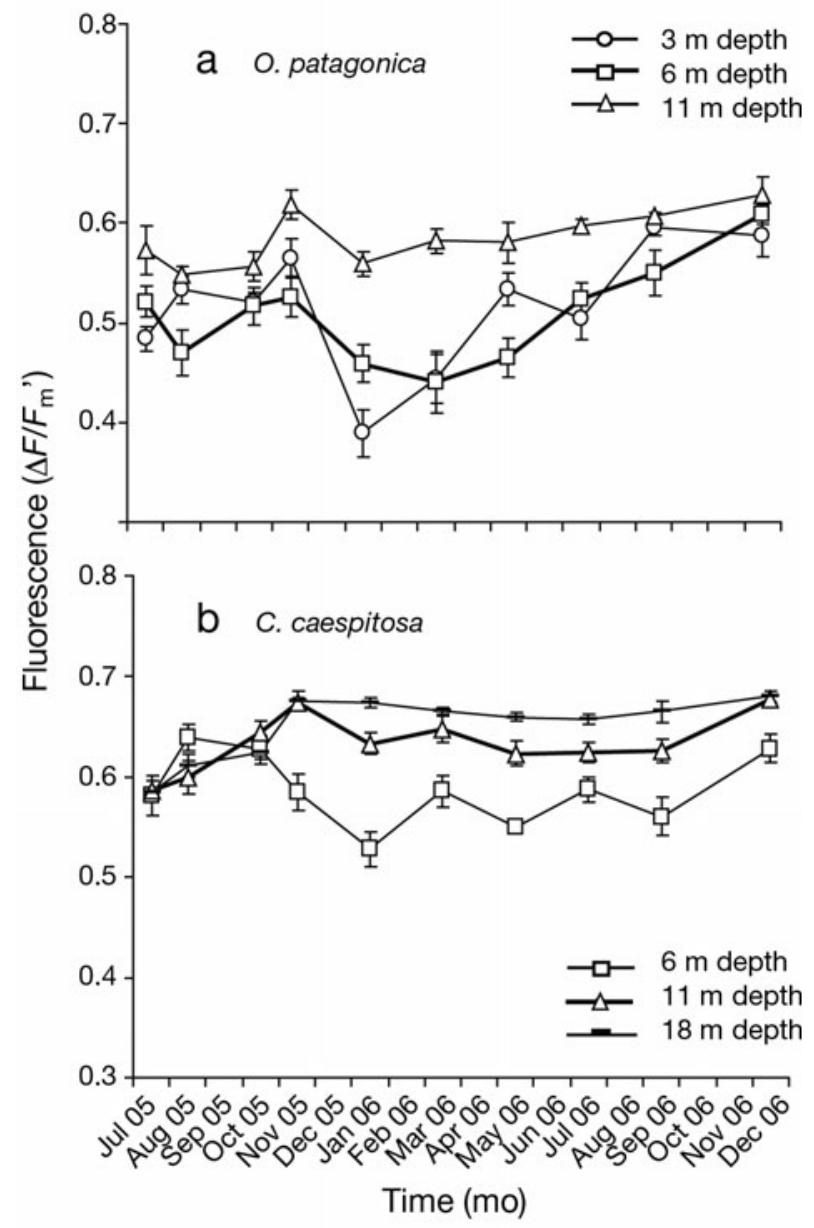

Fig. 6. Mean ( $\pm \mathrm{SE} ; \mathrm{n}=7$ to 8 ) effective quantum yield $\left(\Delta F / F_{\mathrm{m}}{ }^{\prime}\right)$ of (a) Oculina patagonica and (b) Cladocora caespitosa measured at solar midday under clear sky

Diel change in $\Delta F / F_{\mathrm{m}}{ }^{\prime}$ measured during July 2005 and 2006 showed an inverse relationship with PAR for both species (Fig. 7; data for July 2005). Oculina patagonica diel variation in $\Delta F / F_{\mathrm{m}}{ }^{\prime}$ at $3 \mathrm{~m}$ depth (Fig. $7 \mathrm{a}$ ) increased from dawn to $8: 30 \mathrm{~h}$, corresponding to a PAR of around $200 \mu \mathrm{mol} \mathrm{m}{ }^{-2} \mathrm{~s}^{-1}$, and then decreased (26\%) with increasing PAR (1400 $\left.\mathrm{mmol} \mathrm{m}^{-2} \mathrm{~s}^{-1}\right)$ until 13:00 h. Whereas PAR did not substantially decreased during the day, $\Delta F / F_{\mathrm{m}}{ }^{\prime}$ recovered its maximal value by $16: 30 \mathrm{~h}$, corresponding to a PAR of $1300 \mu \mathrm{mol} \mathrm{m}{ }^{-2} \mathrm{~s}^{-1} . \Delta F / F_{\mathrm{m}}{ }^{\prime}$ decline was mostly caused by the concomitant decrease in $F_{\mathrm{m}}{ }^{\prime}(40 \%)$ and $F$ $(20 \%)$. Cladocora caespitosa diel variation in $\Delta F / F_{\mathrm{m}}{ }^{\prime}$ measured at $11 \mathrm{~m}$ depth (Fig. $7 \mathrm{~b}$ ) also increased after dawn and started to decrease at 10:30 h, corresponding to a PAR of around $300 \mu \mathrm{mol} \mathrm{m} \mathrm{m}^{-2} \mathrm{~s}^{-1}$. Similarly to O. patagonica, $\Delta F / F_{\mathrm{m}}{ }^{\prime}$ of $C$. caespitosa decreased by $11 \%$ until 13:00 $\mathrm{h}$. The maximal value was recovered by 16:30 $\mathrm{h}$, when PAR was still at a high value of $350 \mu \mathrm{mol} \mathrm{m} \mathrm{m}^{-2} \mathrm{~s}^{-1}$. The decline in $\Delta F / F_{\mathrm{m}}{ }^{\prime}$ was caused by a concomitant decrease $(40 \%)$ in $F$ and $F_{\mathrm{m}}$ '. These parameters only partially recovered their initial values by the end of the day. 


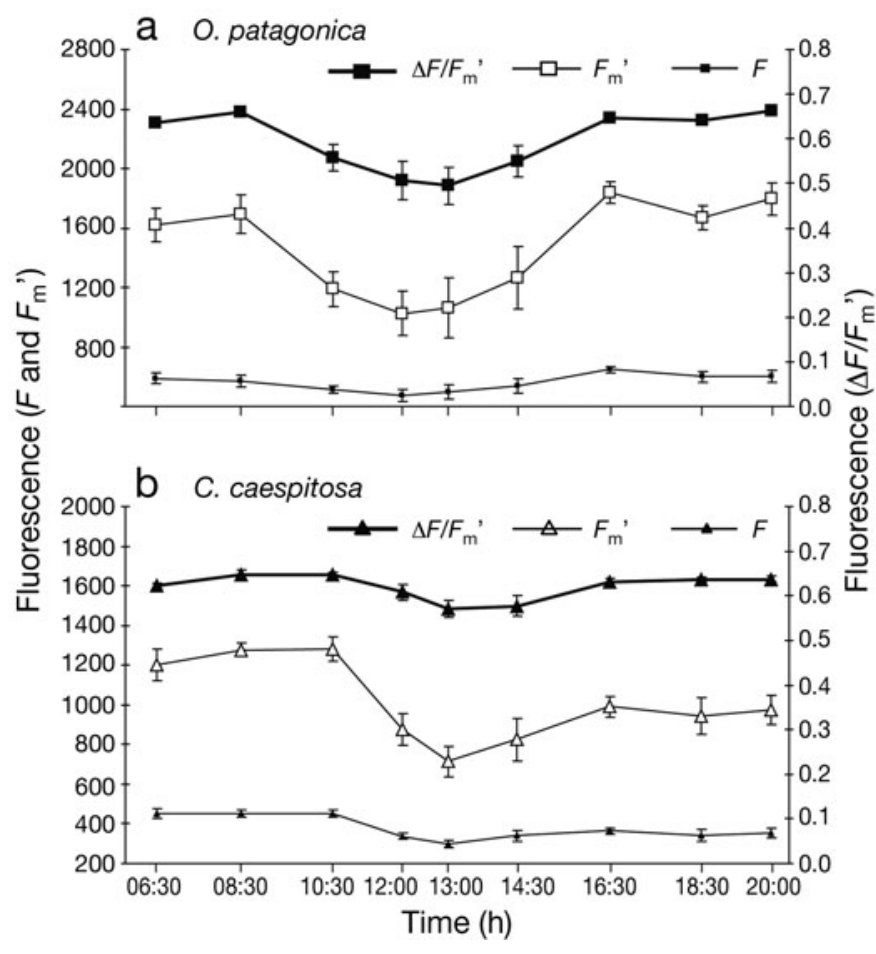

Fig. 7. Diel cycle in mean $( \pm \mathrm{SE} ; \mathrm{n}=7$ ) chlorophyll fluorescence yield $\left(\Delta F / F_{\mathrm{m}}{ }^{\prime}, F\right.$ and $\left.F \mathrm{~m}^{\prime}\right)$ measured on 14 July 2005 from dawn to sunset at (a) $3 \mathrm{~m}$ depth for Oculina patagonica and (b) at $11 \mathrm{~m}$ depth for Cladocora caespitosa. Data in Fig. 2 shows the diel cycle of light measured in parallel with fluorescence

\section{Growth rates}

Except during winter 2006, when temperatures were lower than the optimal values for coral calcification, Oculina patagonica growth rates (Fig. 8a) were always higher at 3 and $6 \mathrm{~m}$ than at $11 \mathrm{~m}$ depth (Table 1). Growth rates increased with an increase in temperature from winter to summer, reaching maximal values of $4.3 \mathrm{mg} \mathrm{g}^{-1} \mathrm{~d}^{-1}$ in August 2005, when corals were near their upper thermal threshold $\left(24\right.$ to $25^{\circ} \mathrm{C}$ ) for the NW Mediterranean. However this elevated temperature, sustained for more than $5 \mathrm{wk}$ during the summer of 2005, was concomitant with a sudden decrease in coral growth rate to ca. 2 to $3 \mathrm{mg} \mathrm{g}^{-1} \mathrm{~d}^{-1}$ by October 2005. This growth pattern differed during the summer of 2006; growth rates measured in July were significantly lower compared to the previous year $\left(3 \mathrm{mg} \mathrm{g}^{-1}\right.$ $\mathrm{d}^{-1}$ ) but remained at this rate much longer (up to September 2006). At 3 and $6 \mathrm{~m}$ depth, growth rates showed a significant, positive relationship with temperature, light radiation and their interaction (multiple regressions, $\mathrm{p}<0.05, \mathrm{n}=10$ ) (Fig. 9). The lateral extension rates of $O$. patagonica measured from July to December 2006 (Fig. 8b) were also significantly higher at 3 than at $11 \mathrm{~m}$ depth (2-way ANOVA, $\mathrm{p}<0.001)$.

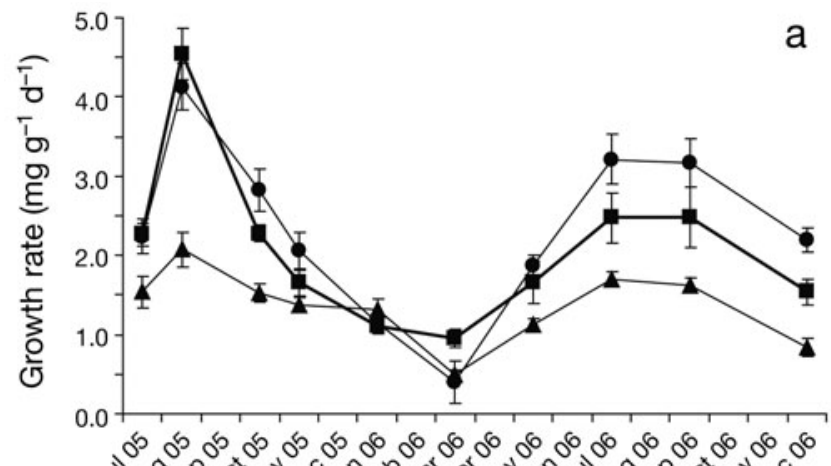

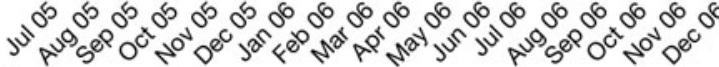

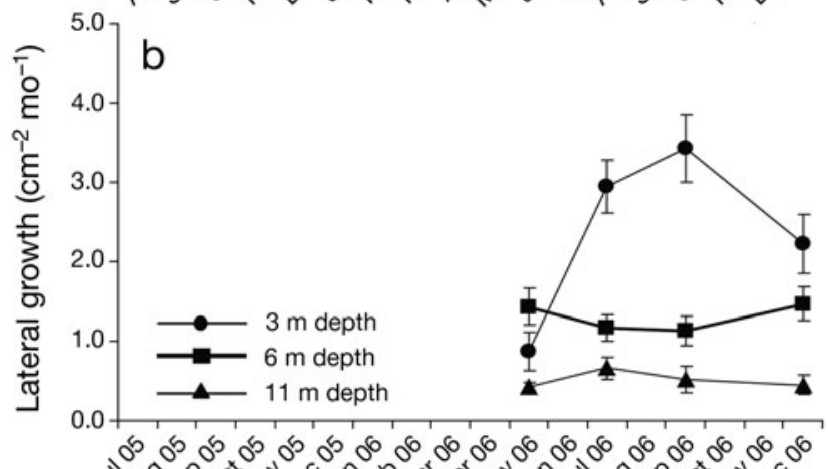

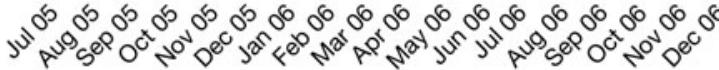

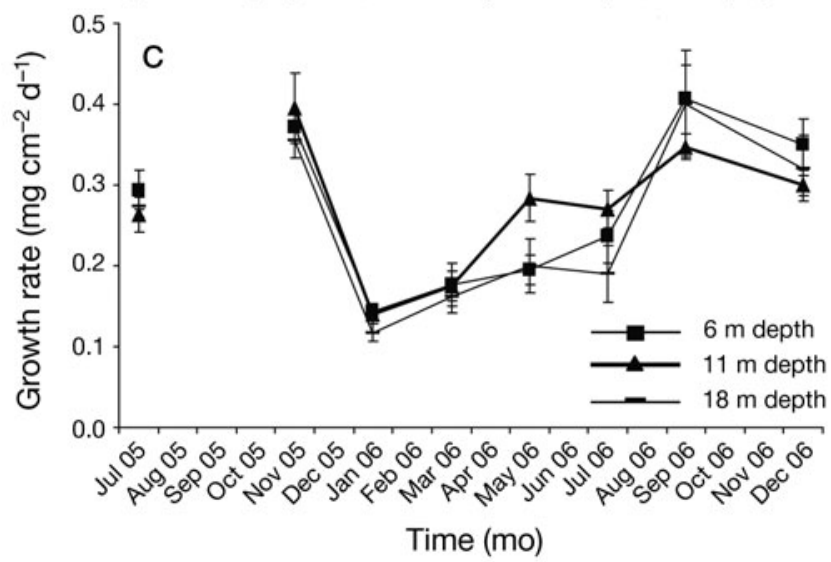

Fig. 8. Mean growth rate $( \pm \mathrm{SE})$ measured for (a) Oculina patagonica $(\mathrm{n}=15)$ and $(\mathrm{c})$ Cladocora caespitosa $(\mathrm{n}=10)$ using the buoyant weight technique. Because of the massmortality event, new samples of $C$. caespitosa were acclimated between September and November 2005 before their growths were measured. (b) Planar growth rate $(n=7)$ of Oculina patagonica, measured by image analysis only from April to November 2006 on healthy nubbins

Growth rates of Cladocora caespitosa measured from November 2005 to December 2006 (Fig. 8c) were not significantly different between depths (Table 1), but significantly increased from January to September (0.12 and $0.35 \mathrm{mg} \mathrm{cm}^{-2} \mathrm{~d}^{-1}$, respectively). Growth rates at each depth showed significant, positive relationships only with temperature (Multiple regression, $\mathrm{p}<$ 0.05, n=7) (Fig. 9). 


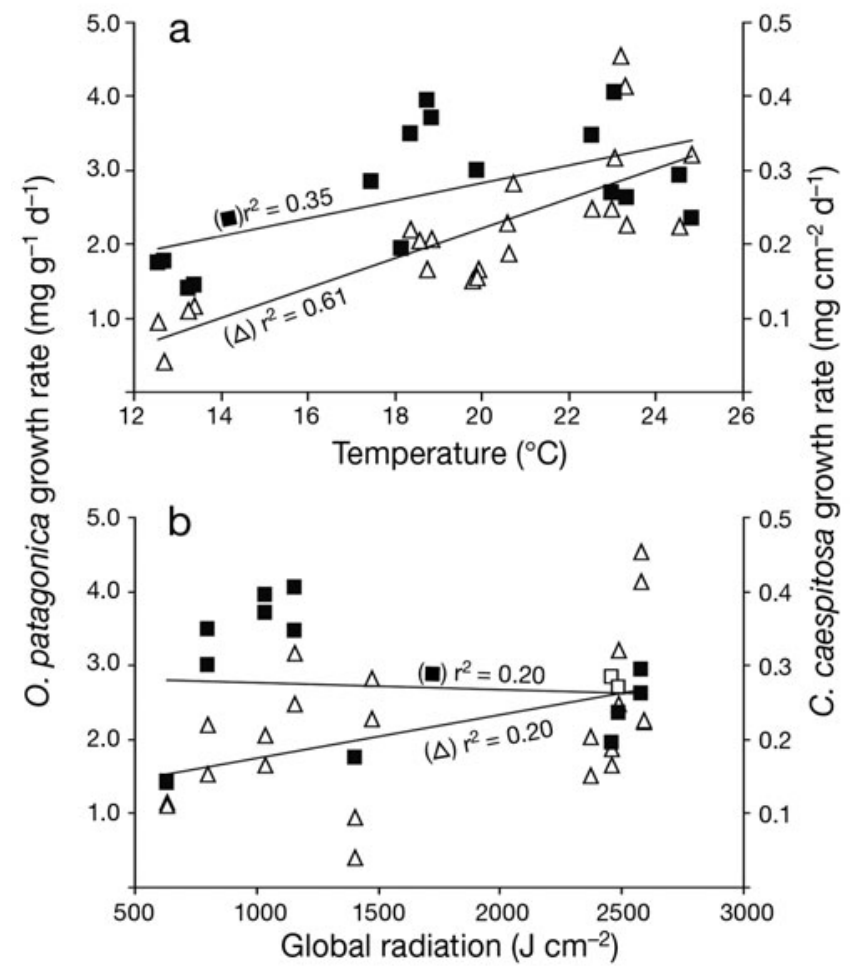

Fig. 9. Relationships between mean Oculina patagonica $\left(\Delta_{1}\right.$ pooled data from 3 and $6 \mathrm{~m}$ depth) or Cladocora caespitosa ( $\mathbf{\square}$, pooled data from 6 and $11 \mathrm{~m}$ depth) growth rates and (a) seawater temperatures, or (b) global terrestrial radiation measured during the 18 mo period (June 2005 to December 2006). The coefficient of the regression is reported as $\mathrm{r}^{2}$

\section{DISCUSSION}

This study highlights the effect of changes in temperature and light on the physiology of 2 temperate Mediterranean corals, Cladocora caespitosa and Oculina patagonica. Observations indicate that the 2 species were more responsive to temperature than to light and suggest that photoacclimation to varying light climates may allow the species to live in well-lit as well as shaded habitats. O. patagonica, an invasive species possibly from the South Atlantic (Zibrowius 1980), behaved like a tropical coral with respect to growth enhancement with increasing light intensity and temperature. In contrast, C. caespitosa, a relict of tropical periods in the Mediterranean Sea, acted as a temperate coral; its growth was less affected by light intensity than by temperature. Finally, we found a differential response of the 2 corals to temperature stress showing that $O$. patagonica is capable of coping better with sustained levels of high temperatures. The different response may be due to a different clade of zooxanthellae inhabiting the 2 corals. Indeed, while zooxanthellae of $C$. caespitosa belong to the temperate clade A (Savage et al. 2002, Visram et al. 2006) zooxanthel- lae of $O$. patagonica collected in the Ligurian Sea (Albissola, Italy), were clade B (D. Forcioli pers. comm.). The temperate clade A seems to be predominant in all Mediterranean symbioses, such as in the corals Cladocora caespitosa, Caryophyllia smithii and Balanophyllia europaea, as well as in sea anemones and gorgonians. Conversely, clade B was only found in the immigrant sea anemone Bunodeopsis strumosa (Visram et al. 2006), and to the best of our knowledge this is the first report in the Mediterranean Sea of a symbiotic association between a scleractinian coral and zooxanthellae belonging to clade B. Similar to tropical symbiotic associations, this different genetic identity might explain some of the different responses and susceptibility to stress of the 2 corals. However, we ignore the clade identity of zooxanthellae of O. patagonica throughout the entire Mediterranean Sea, and a wide comparison between different populations (both in terms of genetics and physiology of host and symbionts) is necessary to make firm conclusions on their potential response to environmental conditions.

In the Ligurian Sea, temperature and light vary greatly throughout the year. While changes in temperature in such environments are well-known (SOMLIT, Service d'Observation en Milieu Littoral; www.domino. u-bordeaux.fr/somlit_national/), few data exist on the temporal and depth-related variation in irradiance levels experienced by corals in this area. However, Peirano et al. (1999) have calculated, using a Secchi disk, the monthly variation in PAR received by Cladocora caespitosa in the Ligurian Sea; the highest value was equal to around $250 \mu \mathrm{mol} \mathrm{m} \mathrm{m}^{-2} \mathrm{~s}^{-1}$ at $3 \mathrm{~m}$ depth and occurred during June-July. In contrast to the natural populations studied by Peirano et al. (1999), our transplanted colonies of Oculina patagonica and C. caespitosa received much higher $\mathrm{PAR}$, especially during summer months (1400 and $1000 \mu \mathrm{mol} \mathrm{m}^{-2} \mathrm{~s}^{-1}$ at 3 and $6 \mathrm{~m}$ depth, respectively). Such transplantation highlighted, for the first time, the important variation in the photophysiology of the symbiotic dinoflagellates inhabiting both corals. Indeed, similarly to tropical corals, shallow colonies had significantly lower and more variable $\Delta F / F_{\mathrm{m}}{ }^{\prime}$ than deeper ones, reflecting down-regulation of PSII activity (i.e. dynamic photoinhibition) in the former and photoacclimation to their relatively low light environment in the latter (Warner et al. 2002). Dynamic photoinhibition at midday is related to one or both photoprotective mechanisms: (1) the xanthophylls conversion (Brown et al. 1999a,b), and (2) the enhanced non-photochemical quenching (NPQ) which dissipates the incoming energy and prevents damage to the photochemical pathway (Gorbunov et al. 2001, Warner \& Berry-Lowe 2006). While to date the xanthophylls conversion is unknown in Mediterranean corals, it has been shown that $C$. cae- 
spitosa easily acclimates to high irradiance levels by a change in the NPQ capacity of the algal cells (RodolfoMetalpa et al. 2008b), as also suggested in the present study by the concomitant decrease $(40 \%)$ in $F$ and $F_{\mathrm{m}}{ }^{\prime}$. Moreover, although the effective quantum yields of O. patagonica and C. caespitosa measured at midday showed some variations during the 18 mo period, they were not related to temperature and light levels, as observed in tropical corals (Warner et al. 2002, Winters et al. 2006), and they did not experience any chronic photoinhibition, except during the winter of 2005 when temperatures were particularly low $\left(\min 11.8^{\circ} \mathrm{C}\right.$ in February 2006 at $3 \mathrm{~m}$ depth). Contrary to tropical corals, for which a recurrent daily photoinhibition usually begins at midday when PAR is near its maximum and persists until late afternoon (Brown et al. 1999a, Gorbunov et al. 2001, Lesser \& Gorbunov 2001, Winters et al. 2003), O. patagonica and C. caespitosa in the Mediterranean showed a slight decrease in $\Delta F / F_{\mathrm{m}}{ }^{\prime}$ starting in the morning as soon as PAR increased, and reached 200 to $300 \mu \mathrm{mol} \mathrm{m}^{-2} \mathrm{~s}^{-1}$, with a rapid recovery starting at midday when light intensity was still maximum. These observations suggest an important photoprotection of the photosystems of these Mediterranean corals to PAR levels similar to those measured in tropical areas (1000 to $2000 \mu \mathrm{mol} \mathrm{m} \mathrm{m}^{-2} \mathrm{~s}^{-1}$; e.g. Jones \& Hoegh-Guldberg 2001, Winters et al. 2003, Mass et al. 2007). This may also explain the ability of these corals to acclimate to a wide range of PAR levels, potentially by the development of non-photochemical quenching (Rodolfo-Metalpa et al. 2008b), which allows the species to live in both well-lit and shaded habitats. High light levels are in agreement with the bathymetric distribution of $O$. patagonica, naturally present in welllit shallow waters, but are contrary to the distribution of C. caespitosa (abundant either in turbid waters or below $10 \mathrm{~m}$ depth). Therefore, the distribution of C. caespitosa does not seem to be governed by light but more by competition with macroalgae (Peirano et al. 1998), which are able to grow more rapidly than C. caespitosa when light is available.

Concerning the association with zooxanthellae, the 2 coral species presented a relatively high density of symbionts per skeletal surface area, similar to previous findings (e.g. Schiller 1993, Rodolfo-Metalpa et al. 2006, Shenkar et al. 2006). These 2 temperate corals also presented some clear similarities with tropical corals in their symbiont response to light and temperature. Zooxanthellae density and chl content of Cladocora caespitosa and Oculina patagonica showed clear temporal and depth variations, even if a significant relationship with temperature and light could only be demonstrated for C. caespitosa. The increase in zooxanthellae and chl concentrations of both corals from winter to spring can be explained by an input of deep inorganic and organic nutrients advected in surface waters by the winter mixing of the water column. High nutrient availability promotes zooxanthellae density in corals (e.g. Houlbrèque et al. 2004, Rodolfo-Metalpa et al. 2008a). The summer reduction in zooxanthellae and chl content may be a response to high light, zooxanthellae receiving sufficient PAR to optimize their photosynthesis, such as observed in tropical corals (Fitt et al. 2000, Warner et al. 2002). Large fluctuations in $O$. patagonica symbiont density have already been reported along the Israeli coasts. Here, consistent with our findings, the species has high concentrations of zooxanthellae and chl during winter and early spring (8.8 zooxanthellae $\mathrm{cm}^{-2}$ and $10.99 \mu \mathrm{g} \mathrm{cm}{ }^{-2}$, respectively; Shenkar et al. 2006), while it gradually loses ca. $90 \%$ of both zooxanthellae and chl content during summer (Shenkar et al. 2006). Other temperate species, such as Plesiastrea versipora (0 to $10 \times 10^{6}$ zooxanthellae $\mathrm{cm}^{-2}$; Kevin \& Hudson 1979, Howe \& Marshall 2001) and Astrangia danae ( 0 to $7 \times 10^{6}$ zooxanthellae $\mathrm{Cm}^{-2}$; Szmant-Froelich \& Pilson 1984), have a larger range of zooxanthellae density per surface area perhaps due to the facultative symbiosis. In contrast to the studied corals, zooxanthellae density in other temperate symbioses, such as in sea anemones, has either remained stable throughout the year (Dykens \& Shick 1984) or was enhanced in summer (Dimond \& Carrington 2007, Verde \& McCloskey 2007).

The present study highlights a different growth response of the 2 corals to light and temperature conditions. Regarding light response, Oculina patagonica behaved like a tropical species, for which growth is typically enhanced by light (e.g. Goreau 1959, Mass et al. 2007). This species indeed showed decreased growth with increasing depth, due to light attenuation (ca. $60 \%$ at $11 \mathrm{~m}$ depth throughout the year). Conversely, no change was observed in the growth of Cladocora caespitosa with depth, although light was attenuated by $80 \%$ at $18 \mathrm{~m}$ depth. This is a characteristic response of temperate corals, for which light does not typically promote growth, such as in Oculina arbuscula (Miller 1995), Astrangia danae (Jacques et al. 1983), and C. caespitosa (Rodolfo-Metalpa et al. 2008a). In contrast to the relationship with light, increase in seawater temperatures significantly enhanced the growth rates of both corals. The stimulation of growth by warm temperatures is consistent with previous experiments performed on both tropical (e.g. Jokiel \& Coles 1977) and temperate corals (Jacques et al. 1983, Miller 1995, Howe \& Marshall 2002, Dimond \& Carrington 2008, Rodolfo-Metalpa et al. 2008a). However, as previously found for C. caespitosa and $O$. patagonica, both with laboratory experiments (Rodolfo-Metalpa et al. 2006) and in situ observations (Rodolfo-Metalpa et al. 2000), when high temperatures 
$\left(\geq 24^{\circ} \mathrm{C}\right.$ ) are maintained for more than $7 \mathrm{wk}$, they cause a progressive decline in calcification due to a general collapse in the corals' physiology. This decline was observed in summer 2005 for both species, when temperatures equaled $24^{\circ} \mathrm{C}$ or above for several weeks between July and September.

The response to the temperature stress of the summer of 2005 was, however, different between Oculina patagonica and Cladocora caespitosa. While only $30 \%$ of O. patagonica nubbins showed signs of tissue degradation, $80 \%$ of $C$. caespitosa samples were affected, suggesting a different host susceptibility to elevated temperature, perhaps due to different protective mechanisms (e.g. stress proteins, antioxidant enzymes) (Brown 1997). These results support our hypothesis that shallow water corals are living, at least in the North Mediterranean, near their upper thermal limits during summer (Rodolfo-Metalpa et al. 2006). Since the frequency of abnormally warm summers may increase in the next century, as a result of climate change, such mortality events in summer may also become more frequent as a direct response to elevated temperatures.

Acknowledgements. This research was supported by the Centre Scientifique of Monaco. H. Zibrowius (CNRS, France) provided helpful comments on Oculina patagonica transplantation methods. We thank A. Peirano (ENEA, Italy) for coral collection, F. Pacorel, M. Dagnino (Musée Oceanographique de Monaco) and R. Graille (CNRS, France) for video and photographs, as well as C. Richard and C. Rottier for dive assistance and laboratory analyses. We are indebted to the staff of the Police Maritime of Monaco who assisted in fieldwork, and to M. Krettly and E. Lafont (Musée Oceanographique de Monaco) for logistical field support. We also thank D. Forcioli (University of Nice, France) for genetic analysis of zooxanthellae as well as 3 anonymous reviewers for their helpful comments.

\section{LITERATURE CITED}

Brown BE (1997) Coral bleaching: causes and consequences. Coral Reefs 16:S129-S138

Brown BE, Ambarsari I, Warner ME, Fitt WK, Dunne RP, Gibb SW, Cummings DG (1999a) Diurnal changes in photochemical efficiency and xanthophyll concentrations in shallow water reef corals: evidence for photoinhibition and photoprotection. Coral Reefs 18:99-105

Brown BE, Dunne RP, Ambarsari I, Le Tissier MDA, Satapoomin U (1999b) Seasonal fluctuations in environmental factors and variations in symbiotic algae and chlorophyll pigments in four Indo-Pacific coral species. Mar Ecol Prog Ser 191:53-69

Coma R, Ribes M, Gili JM, Zabala M (2000) Seasonality in coastal benthic ecosystems. Trends Ecol Evol 15:448-453

Coma R, Ribes M, Gili JM, Zabala M (2002) Seasonality of in situ respiration rate in three temperate benthic suspension feeders. Limnol Oceanogr 47:324-331

> Dimond J, Carrington E (2007) Temporal variation in the symbiosis and growth of the temperate scleractinian coral Astrangia poculata. Mar Ecol Prog Ser 348:161-172

Dykens JA, Shick JM (1984) Photobiology of the symbiotic sea anemone, Anthopleura elegantissima: defenses against photodynamic effects and seasonal photoacclimatization. Biol Bull 167:683-697

Fine M, Zibrowius H, Loya Y (2001) Oculina patagonica: a non-lessepsian scleractinian coral invading the Mediterranean Sea. Mar Biol 138:1195-1203

Fitt WK, McFarland FK, Warner ME, Chilcoat GC (2000) Seasonal patterns of tissue biomass and densities of symbiotic dinoflagellates in reef corals and relation to coral bleaching. Limnol Oceanogr 45:677-685

Gorbunov MY, Kolber ZS, Lesser MP, Falkowski PG (2001) Photosynthesis and photoprotection in symbiotic corals. Limnol Oceanogr 46:75-85

$>$ Goreau TF (1959) The physiology of skeleton formation in corals. I. A method for measuring the rate of calcium deposition by corals under different conditions. Biol Bull 116: $59-75$

> Houlbrèque F, Tambutté E, Richard C, Ferrier-Pagès C (2004) Importance of a micro-diet for scleractinian corals. Mar Ecol Prog Ser 282:151-160

Howe SA, Marshall AT (2001) Thermal compensation of metabolism in the temperate coral Plesiastrea versipora (Lamarck, 1816). J Exp Mar Biol Ecol 259:231-248

Howe SA, Marshall AT (2002) Temperature effects on calcification rate and skeletal deposition in the temperate coral, Plesiastrea versipora (Lamarck). J Exp Mar Biol Ecol 275: 63-81

Jacques TG, Marshall N, Pilson MEQ (1983) Experimental ecology of the temperate scleractinian coral Astrangia danae. II. Effect of temperature, light intensity and symbiosis with zooxanthellae on metabolic rate and calcification. Mar Biol 76:135-148

Jeffrey SW, Humphrey GF (1975) New spectrophotometric equations for determining chlorophylls $\mathrm{a}, \mathrm{b}, \mathrm{c}_{1}$ and $\mathrm{c}_{2}$ in higher plants, algae and natural phytoplankton. Biochem Physiol Pflanz 167:191-194

Jokiel PL, Coles SL (1977) Effect of temperature on the mortality and growth of Hawaiian reef coral. Mar Biol 43: 201-208

Jones RJ, Hoegh-Guldberg O (2001) Diurnal changes in the photochemical efficiency of the symbiotic dinoflagellates (Dinophyceae) of corals: photoprotection, photoinactivation and the relationship to coral bleaching. Plant Cell Environ 24:89-99

> Kevin KM, Hudson RCL (1979) The role of zooxanthellae in the hermatypic coral Plesiastrea urvillei (Milne Edwards and Haime) from cold waters. J Exp Mar Biol Ecol 36: $157-170$

Lesser MP, Gorbunov MY (2001) Diurnal and bathymetric changes in chlorophyll fluorescence yields of reef corals measured in situ with a fast repetition rate fluorometer. Mar Ecol Prog Ser 212:69-77

Marsh YA (1970) Primary productivity of reef-building calcareous and red algae. Ecology 55:225-263

> Mass T, Einbinder S, Brokovich E, Shashar N, Vago R, Erez J, Dubinsky Z (2007) Photoacclimation of Stylophora pistillata to light extremes: metabolism and calcification. Mar Ecol Prog Ser 334:93-102

Miller MW (1995) Growth of a temperate coral: effects of temperature, light, depth and heterotrophy. Mar Ecol Prog Ser 122:217-225

> Muller-Parker G, Davy SK (2001) Temperate and tropical algal-sea anemone symbioses. Invertebr Biol 120:104-123

Peirano A, Morri C, Mastronuzzi G, Bianchi CN (1998) The coral Cladocora caespitosa (Anthozoa, Scleractinia) as a bioherm builder in the Mediterranean Sea. Mem Descr Carta Geol d'It 52:59-74 
Peirano A, Morri C, Bianchi CN (1999) Skeleton growth and density pattern of the temperate, zooxanthellate scleractinian Cladocora caespitosa from the Ligurian Sea (NW Mediterranean). Mar Ecol Prog Ser 185:195-201

Peirano A, Abbate M, Cerrati G, Difesca V, Peroni C, RodolfoMetalpa R (2005) Monthly variations in calyx growth, polyp tissue, and density banding of the Mediterranean scleractinian Cladocora caespitosa (L.). Coral Reefs 24: 404-409

Rodolfo-Metalpa R, Bianchi CN, Peirano A, Morri C (2000) Coral mortality in NW Mediterranean. Coral Reefs 19:24

Rodolfo-Metalpa R, Richard C, Allemand D, Ferrier-Pagès C (2006) Growth and photosynthesis of two Mediterranean corals Cladocora caespitosa and Oculina patagonica under normal and elevated temperatures. J Exp Biol 209: $4546-4556$

Rodolfo-Metalpa R, Peirano A, Houlbrèque F, Abbate M, Ferrier-Pagès C (2008a) Effect of temperature, light and heterotrophy on the growth rate and budding of the temperate coral Cladocora caespitosa. Coral Reefs 27:17-25

Rodolfo-Metalpa R, Huot Y, Ferrier-Pagès C (2008b) Photosynthetic response of the Mediterranean zooxanthellate coral Cladocora caespitosa to different light and temperature conditions. J Exp Biol 211:1579-1586

Savage AM, Goodson MS, Visram S, Trapido-Rosenthal H, Wiedenmann J, Douglas AE (2002) Molecular diversity of symbiotic algae at the latitudinal margins of their distribution: dinoflagellates of the genus Symbiodinium in corals and sea anemones. Mar Ecol Prog Ser 244:17-26

Schiller C (1993) Ecology of the symbiotic coral Cladocora caespitosa (L.) (Faviidae, Scleractinia) in the Bay of Piran (Adriatic Sea). II. Energy budget. PSZN I Mar Ecol 14: 221-238

Shenkar N, Fine M, Kramarsky-Winter E, Loya Y (2006) Population dynamics of zooxanthellae during a bacterial bleaching event. Coral Reefs 25:223-227

Spencer Davies P (1989) Short-term growth measurements of corals using an accurate buoyant weighing technique. Mar Biol 101:389-395

Stimson J (1997) The annual cycle of density of zooxanthellae

Editorial responsibility: Brian Helmuth,

Columbia, South Carolina, USA in the tissues of field and laboratory-held Pocillopora damicornis (Linnaeus). J Exp Mar Biol Ecol 214:35-48

Szmant-Froelich A, Pilson MEQ (1984) Effects of feeding frequency and symbiosis with zooxanthellae on nitrogen metabolism and respiration of the coral Astrangia danae. Mar Biol 81:153-162

Underwood AJ (1997) Experiments in ecology: their logistical interpretation and design. Cambridge University Press, Cambridge

Vago R, Dubinsky Z, Genin A, Ben-Zion A, Kizner Z (1997) Growth rates of three symbiotic corals in the Red Sea. Limnol Oceanogr 42:1814-1819

> Verde EA, McCloskey LR (2007) A comparative analysis of the photobiology of zooxanthellae and zoochlorellae symbiotic with the temperate clonal anemone Anthopleura elegantissima (Brandt). III. Seasonal effects of natural light and temperature on photosynthesis and respiration. Mar Biol 152:775-792

Visram S, Wiedenmann J, Douglas AE (2006) Molecular diversity of symbiotic algae of the genus Symbiodinium (Zooxanthellae) in cnidarians of the Mediterranean Sea. J Mar Biol Assoc UK 86:1281-1283

- Warner ME, Berry-Lowe S (2006) Differential xanthophylls cycling and photochemical activity in symbiotic dinoflagellates in multiple locations of three species of Caribean coral. J Exp Mar Biol Ecol 339:86-95

> Warner ME, Chilcoat GC, McFarland FK, Fitt WK (2002) Seasonal fluctuations in the photosynthetic capacity of photosystem II in symbiotic dinoflagellates in the Carribean reef-building coral Montastrea. Mar Biol 141:31-38

Winters G, Loya Y, Rötgers R, Beer S (2003) Photoinhibition in shallow-water colonies of the coral Stylophora pistillata as measured in situ. Limnol Oceanogr 48:1388-1393

Winters G, Loya Y, Beer S (2006) In situ measured seasonal variations in $F_{\mathrm{v}} / F_{\mathrm{m}}$ of two common Red Sea corals. Coral Reefs 25:593-598

Zibrowius H (1980) Les scléractiniaires de la Méditerranée et de l'Atlantique nord-oriental. Mem Inst Oceanogr Monaco, Monaco

Submitted: January 22, 2008; Accepted: June 16, 2008

Proofs received from author(s): September 21, 2008 